\title{
Analysis of the Reasons for the Absence of Slums in China and the Phenomenon of Quasi Slums-Based on the Comparison with India
}

\author{
Jiayan Zhang \\ College of Urban Planning and Architecture, Southwest Minzu University, Chengdu, China \\ Email: 1923170265@qq.com
}

How to cite this paper: Zhang, J.Y. (2021) Analysis of the Reasons for the Absence of Slums in China and the Phenomenon of Quasi Slums-Based on the Comparison with India. Open Access Library Journal, 8: e7925. https://doi.org/10.4236/oalib.1107925

Received: September 3, 2021

Accepted: September 14, 2021

Published: September 17, 2021

Copyright $\odot 2021$ by author(s) and Open Access Library Inc.

This work is licensed under the Creative Commons Attribution International License (CC BY 4.0).

http://creativecommons.org/licenses/by/4.0/

\begin{abstract}
In recent years, many scholars are very interested in why there are no slums in China. This study aims to reveal the essential reasons why there are no slums in Chinese cities and analyze the hidden dangers behind them. This paper analyzes China's land property rights system, urban-rural dual structure and current situation of urbanization. Also, the paper puts forward that India's private ownership is unreasonable, farmers' social status is poor, and property rights control seriously threatens farmers' property rights, resulting in no improvement in their income. However, China's rural resources and assets have been more protected, and farmers have certain resource rights and can realize self-development. Therefore, there is no substantive slum problem in China. However, the existing "quasi slums" problem cannot be underestimated and must be paid attention to, otherwise it will be possible to turn into slums.
\end{abstract}

\section{Subject Areas}

Urban Planning

\section{Keywords}

Slum, Property Rights Control, Urban-Rural Dual, The Shanty Towns, Low-Renting Public Housing

\section{Introduction}

"Slum" is a long-standing urban social phenomenon. At present, it widely exists in densely populated developing countries and regions such as India. According to the latest data released by the United Nations, the slum population in India has reached 170 million, accounting for $12.69 \%$ of the total population. These 
slums, known as "the root of urban disaster" and "the cancer of the city", began to surround the city gradually, and the urban society has faced unprecedented challenges [1].

For China, with the great economic achievements since the reform and opening-up, China's urbanization has been developing rapidly. According to the data of China's seventh national census, China's urban permanent population is 90.199 million, accounting for $63.89 \%$ of the total population. By 2035, China's urbanization rate is expected to reach more than $75 \%$. For a long time, the discussion of poverty in China is often limited to rural poverty. With the continuous acceleration of urbanization in recent years, researchers began to pay attention to the poverty problem of the emerging urban population and regard it as a social problem. Exploring the common slum problems in modern countries has important theoretical and application value for China to promote the process of urbanization orderly, healthily and coordinately. This paper hopes to analyze China's property right system and urbanization by comparing it with India, in order to avoid the transformation of China's existing shantytowns and public rental houses into slums.

\section{Current Situation of Urbanization in China}

Over the past 70 years since the founding of the People's Republic of China, reform of the housing system has been deepened, and government-subsidized housing projects have been accelerated. We have built more than 80 million government-subsidized housing units of various types and relocated housing units in rundown areas, helping more than 200 million people solve their housing difficulties and establishing the world's largest housing security system. At present, China is in a new phase of poverty alleviation. In 2011, China actively carried out poverty alleviation policy innovation, and formulated the outline of poverty alleviation and development in China's rural areas. The file points out that, until 2020, for China to implement the comprehensive well-off, guarantee the poverty problem is resolved in the poor areas, realize the comprehensive well-off, community residents can enjoy the good life, will be the neediest areas of China as an important area for poverty alleviation, formulate reasonable poverty methods, will be China's rural labor force as the center of gravity of the poverty alleviation work [2].

Since 2010, China has experienced the largest and fastest urbanization process in world history. Statistics show that at the end of 2018, the urbanization rate of China's permanent population reached 59.58\%, 48.94 percentage points higher than that at the end of 1949 , with an average annual increase of 0.71 percentage points.

Nowadays, reform of the housing system has been deepened, and government-subsidized housing projects have been accelerated. We have built more than 80 million government-subsidized housing units of various types or housing units that have been renovated or resettled in rundown areas, helping more 
than 200 million people solve their housing difficulties, and establishing the largest housing security system in the world.

\section{Analysis of the Reasons Why there Are No Slums in China-Based on the Comparison with India}

\subsection{Reasons for the Formation of Slums}

From the perspective of causes, in some developing countries and even developed countries, a large number of rural populations rapidly migrated to cities, and residents built a large number of self-owned houses spontaneously and illegally. However, cities could not accept the influx of such a large number of people, and the progressive urbanization and deindustrialization led to the formation of slums.

In China, the village in the city was originally the suburban countryside under the rural collective land ownership, but it was incorporated into the city due to the urban expansion [3]. In this regard, with the continuous expansion of cities, rural collective land is transformed into urban land, which has become the only way for urban expansion. After farmland is expropriated, the remaining homestead sites become urban villages surrounded by cities.

The property rights of houses in urban villages in China are clear, which are the free homestead of farmers, so the security and legality of houses will be guaranteed. Compared with foreign government departments, Chinese governments at all levels have been actively and sparing no effort to transform the living environment of urban villages.

To sum up, there are two main reasons for the formation of slums: first, a large number of farmers pour into cities and build their own houses, which form slums due to the low environment and quality; Second, due to urban expansion, urban villages appear in suburban areas, and the governments of some countries do not pay enough attention to the supervision and development of urban villages.

\subsection{Differences in Land Property Right Systems}

China and India have different land property rights. China uses a rural land system of collective ownership, while India focuses on private ownership. Moreover, ownership of resources does not guarantee rational use of resources. In fact, instead of private ownership in India, China has adopted collective ownership, which gives Chinese farmers more property rights. We can conclude that Chinese farmers have their own land property rights based on the household contract responsibility system, excluding the right of "farming to non-farming" and sale. But what is completely different is the private ownership of land formulated in India. On the surface, the land ownership of farmers in India belongs to them, but in fact, the property rights of farmers are restricted by multiple aspects. For example, after India's independence, in order to actively drive the country's farmers to cultivate their own land, various Indian states have implemented rela- 
tively strict management on rural land lease. The actual purpose of buying, selling and transforming rural land in India requires strict approval by India's state governments [4].

At present, many cities in China are open to farmers, so there are many "new citizens", but the countryside is not completely open to cities. The most typical example is that it is easy for farmers to change their rural household registration into urban household registration, but it is almost impossible for them to change their urban household registration into rural household registration. In addition, urban capital (including urban citizens) cannot go to the countryside to buy farmers' homestead and housing.

The reason why the government restricts urban capital from going to the countryside is that if urban capital builds holiday villas in the countryside, it will lose the basic security that farmers rely on in the countryside if they fail to go to the countryside and return to the countryside [5]. Therefore, the current urban-rural dual system is a "protective urban-rural dual system" that allows farmers to enter the city freely, but does not allow capital to go to the countryside freely.

As the "retreat way" for farmers to go to cities, small-scale farming based on family agriculture not only provides homestead and housing for farmers, so that "residents have their own houses", but also provides farmers with income from the land to provide security. "Acquaintance society" based on agricultural production was also established. This is a rural life with roots, a sense of physical security and a sense of spiritual belonging. It is also because of this fallback that China is the only developing country without large-scale urban slums. As long as farmers can integrate with the land, they will have basic security, and any difficulties encountered in China's development process will be able to "soft landing", thus contributing greatly to China's social stability.

\subsection{The Existence of New Urbanization}

On September 26, 2020, the Minister of housing and urban rural development revealed that in the 70 years since the founding of new China, the reform of the housing system has been deepened, the affordable housing project has been accelerated, and more than 80 million sets of affordable housing and shed reform resettlement housing have been built, which has helped more than 200 million people solve their housing difficulties and built the largest housing security system in the world.

In the future, there will be several shifts in China's urbanization: from quantity priority to quality priority; from pursuing economic growth to comprehensive indicators of economic, social and environmental development; from paying attention to the city macro overall to people-oriented transformation. China's urbanization level will reach 70 percent by 2035 and 80 percent by 2050, which is also consistent with the general law of urbanization development.

Taking Deqing County of Zhejiang Province as an example, it is the only pilot 
county of urban and rural system reform in Zhejiang, which can well represent the achievements of China's new urbanization. In order to promote the integration of urban and rural areas, Deqing County initiated the reform of registered residence system in June 2012. In accordance with the idea of "protecting rights, retaining profits, increasing profits", the rural property rights system was continuously improved, the level of basic public services was improved, and the population of agricultural transfer population was promoted. In 2015, the urbanization rate of Deqing County reached 65\% and the per capita GDP reached 91300 yuan. The process of new urbanization characterized by the integrated development of urban and rural areas was comprehensively accelerated.

In the future, we should steadily promote the reform of the household registration system, focus on the implementation of reform measures in the population inflow areas, and further relax restrictions on the population that has been employed in cities for a long time to stimulate consumer demand. On the other hand, we should speed up the reform of the rural land management system, open the scope of circulation, and bring more income expectations to farmers.

China is making continuous efforts in the following aspects: First, put an end to real estate speculation, strengthen the housing function and weaken its economic function. Second, we need to improve the housing security system so that families who really need housing but lack the ability to pay can get governmentsubsidized housing support and move to cities. Third, improve the housing market system, vigorously develop rental housing, so that new migrant workers in cities can have a legal, harmonious and stable place to live when they are unable to buy their own property right housing.

Therefore, in the 70 years since the founding of the People's Republic of China, the people have been masters of the country, economic construction has developed rapidly, living standards have improved significantly, and earth-shaking changes have taken place in clothing, food, housing and transportation. As far as I know, there have been no slums in China before and most likely will not be in the future.

\subsection{The Existence of Urban-Rural Dual Structure}

Compared with the past urban-rural dual structure with the household registration system as the core of the city's restrictions on the transfer of peasants into the city, the institutional restrictions of the existing urban-rural dual structure have been greatly reduced. The main limitation of whether the peasants registered residence in the city is employment and income barriers: it is difficult for the peasants to get stable employment and income in the cities. One of the results of their rational decision-making is to retain the way back to the countryside. Therefore, the current urban-rural dual structure is changing from institutional urban-rural dual structure to market-oriented urban-rural dual structure. There are few factors that make farmers unable to enter the city due to institutional constraints. 
However, this does not mean that the institutional urban and rural dual structure is no longer there. It still exists. There are two main things. First, megacities such as Beijing, Shanghai and Guangzhou have relatively strict regulations on household registration management and population migration, which has a particularly great impact on education. One reason why megacities such as Beijing, Shanghai and Guangzhou restrict population migration is that the population size of these cities is already too large and the urban environmental carrying capacity is limited. Cities below the provincial capital have basically liberalized household registration management, so it is relatively easy for farmers to move in as long as they have economic capacity. Second, the current institutional arrangements for urban capital and urban population to the countryside also have certain restrictions. Generally speaking, the current rural basic management system does not allow rural land to be bought and sold, nor does it allow urban residents to buy farmers' homesteading and houses in the countryside, so that rural residents can return to their hometowns regardless of whether they can live decently in the cities. In this way, the current urban-rural dual structure has become an institutional arrangement to protect farmers, especially vulnerable groups. In this sense, the current urban-rural dual structure in China is still institutional. The difference is that in the past, the urban-rural dual structure was an exploitative structure for farmers, but now it has become a protective structure for farmers. From the exploitative urban-rural dual structure to the protective urban-rural dual structure, it is an amazing creative transformation of urban-rural dual structure quietly.

It is the existence of the protective urban-rural dual structure that makes almost all rural residents in cities still have their hometowns, contracted land, homestead and housing. When the urban farmers have not yet bought a house in the city, they do not have the employment and income conditions to survive in the city, although they also hope that they can obtain stable urban employment and higher income, and thus become a member of the urban middle class, they will not rush to regard themselves as urban people. They are still the people of their hometown, the passers-by in the city, the people who make money in the city and live in their hometown. Home is the destination, is the hope, is to achieve the meaning of life place. In fact, most of the parents and children of migrant workers are still living in their home villages.

In this way, as the migrant farmers work and do business in cities for a long time, there will be differentiation. Some farmers are lucky or have professional skills and have obtained the economic income that can survive in cities decently. These farmers can take their parents and children who stay in the countryside to the cities and become urban people together. As a result, what professor Zhang Zheng of Peking University has discussed is the "unemployment of middle-aged farmers". They are unable to live decently in cities and it is even more difficult for their rural parents and children to live in cities, so they choose to return home. 
As a result, China's migrant farmers do not end up in rootless urban slums that lack basic security, decency and dignity, and thus China do not have the large-scale urban slums found in almost all other developing countries.

However, under the "protective urban-rural dual system", a very prominent problem cannot be ignored, that is, rural families with strong ability and high income will choose to go to cities, and urbanization is the development trend in the future, which will inevitably lead to the widening income gap between Urban and rural areas in China.

Therefore, it is more and more important to provide basic security for the farmers who lack the ability to enter the city. This requires that the focus of agricultural resources in the Rural Revitalization Strategy should be inclined to these peasant groups. Rural areas provide farmers with basic production and living security, so that those who fail to enter cities are unwilling to drift in cities. Thus, the country gets rural areas as a stabilizer and reservoir.

\section{Overall Comparison and Poverty Reduction Effect of China and India}

Most Western experts believe that India focuses on private ownership, while China adopts a state-owned, collective-owned economy. Therefore, China's economic development and poverty reduction work are better than India's. As a matter of fact, with private ownership as the dominant force, India's resource property rights have been violated to a certain extent and have been more controlled. On the contrary, China actively implements state ownership and collective ownership, which can well protect the property rights of resources. Because the real market economy is not as private ownership, but adopts normative property rights definition and security as the foundation, so we can believe that China is an economic country in a practical sense, which also determines that China can give better play to the value of resource allocation, better than India, optimize resources in rural areas and achieve the effect of poverty reduction [6].

Such institutional differences can be reflected in the different division and protection of resource property rights between China and India. Table 1 shows the difference between India and China in three aspects. According to the property rights analysis of land resources in the two countries, when China implements

Table 1. Comparison of China and India on ownership, land resource and personal rights.

\begin{tabular}{|c|c|c|}
\hline & \multicolumn{2}{|c|}{ Comparison of China and India } \\
\hline & India & China \\
\hline Ownership & Private ownership & State-owned, Collective-owned \\
\hline $\begin{array}{l}\text { Distribution of } \\
\text { land resources }\end{array}$ & $\begin{array}{l}\text { The distribution is unbalanced and } \\
\text { damages the interests of farmers }\end{array}$ & $\begin{array}{l}\text { The government promotes the fair } \\
\text { distribution of land to farmers }\end{array}$ \\
\hline Personal rights & $\begin{array}{c}\text { Discrimination against women and strict } \\
\text { control of labor laws and regulations }\end{array}$ & Protection of citizens' personal rights \\
\hline
\end{tabular}


land reform, the national government will actively promote it, eliminate the landlord class, and fairly divide the land into the hands of each farmer. On the surface, the land ownership belongs to the village, but in fact, the specific rights of property rights are distributed to each farmer. However, in India, land reform is based on the Democratic electoral system of The United Kingdom. The traditional landlord class has certain interference, and the land distribution is not balanced enough, resulting in the loss of farmers' interests [7]. On the surface of private ownership, but in reality, each right will be affected in many ways. According to the existing analysis of human resource property rights, China has a good respect for sex, unlike India, where the discrimination against women is more serious. Moreover, China does not implement strict labor laws and regulations like India, which makes China's human resource property rights more protected, while India does not.

After analysis, there are many differences in rural land resource property rights and human resource property rights systems between China and India. Such differences lead to that China's property rights protection is better than India's property rights protection. Chinese farmers have a variety of resource rights, which also gives Chinese farmers certain land use rights, free division of labor and provides more development opportunities, this can also improve China's poverty eradication efficiency [8].

\section{The Problems of Farmers and "Quasi Slums" behind the Glamour}

\subsection{Farmers}

The absence of slums in our cities is a means to restrict the migration of rural people into cities, at the expense of a large number of rural people losing the right to free movement and other benefits. Specifically, it is difficult to obtain urban residence certificate, which means that it is difficult to enjoy all kinds of urban welfare tied to urban residence certificate, including education, medical care, housing and other urban public services equally. That is to say, the glamour of Chinese cities comes at the expense of some citizens' rights. It is the peasants' great efforts that make the city bright. China is not without slums, just not in the cities, but institutionalized in the countryside.

\subsection{The "Quasi-Slums" Problem}

1) Shantytowns

China also has a "quasi-slum" phenomenon, that is, shantytown, which deserves attention, but it is not as serious as many developing countries, and the causes are not the same. As shown in Figure 1, Shantytowns refer to the places where houses are concentrated in cities with simple structure, poor disaster resistance (poor earthquake resistance, fire prevention and flood control), crowded living, poor functions (several generations living in the same room, no water supply and drainage, and no gas supply and heating), and poor living environment 


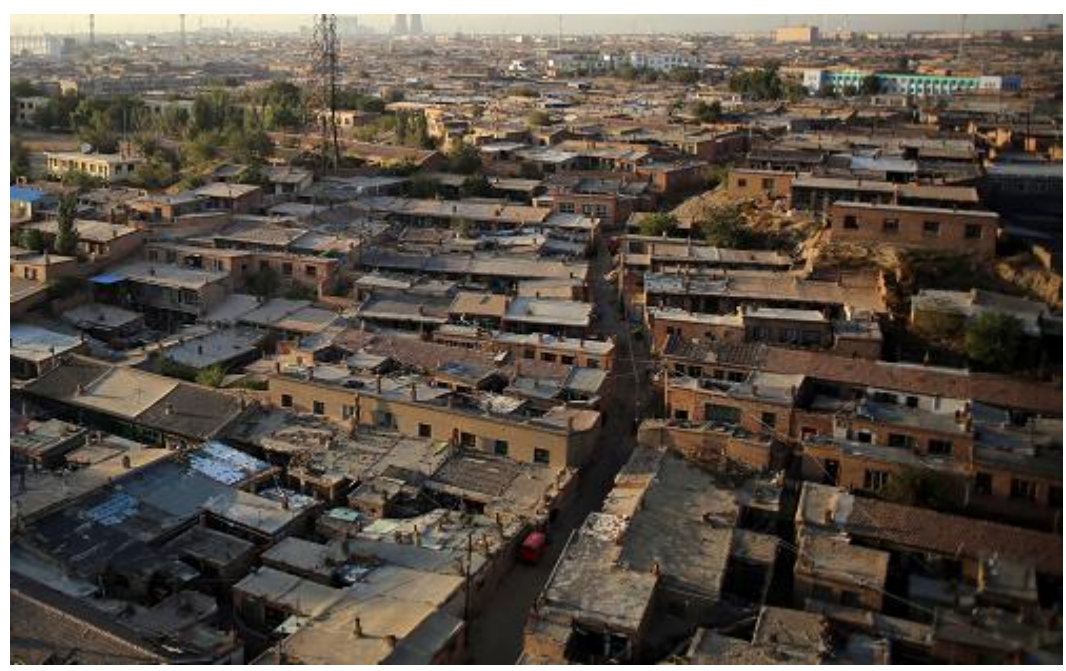

Figure 1. A chaotic shantytown.

(disorderly discharge of feces and garbage, no roads, no greening, no public activity sites, and poor lighting and ventilation). Shanty towns in China are mainly divided into two categories, and the two categories cannot be completely separated [9]. One kind can be called urban corner, mainly including the inner-city areas which are generally forgotten in the urban development and construction due to various reasons. The other is the shantytown formed by a large number of farmers who enter the city to live in sheds during the urbanization process. The living conditions of this shantytown are worse than those in the corners of the city in various aspects, such as infrastructure, health facilities, safety conditions and geographical location.

2) Public rental housing

Public rental housing refers to government-subsidized housing provided by the government with policy and financial support, limited apartment size and preferential rent standards for eligible families [10].

In terms of public rental housing construction, there are three main problems, all of which may induce public rental housing to transform into slums to a certain extent. First, the lack of standardized, scientific and efficient construction and management mode of public rental housing leads to poor supporting facilities and confusion in public rental community management. Second, the lack of scientific analysis of the demand scale of public rental housing and the mechanism of local guarantee capacity leads to the problems of "concentrated area and concentrated scale" in the construction scale of public rental housing and insufficient funds in the operation and management of public rental housing. Third, the affordable and transitional nature of public rental housing is overemphasized and the commodity attributes of public rental housing are ignored, which leads to low construction standards and limited funding channels for public rental housing construction. For example, some "capsule apartment", "container room" and other phenomena appear in big cities where housing prices are constantly rising. Figure 2 indicates the transformation process of public rental 


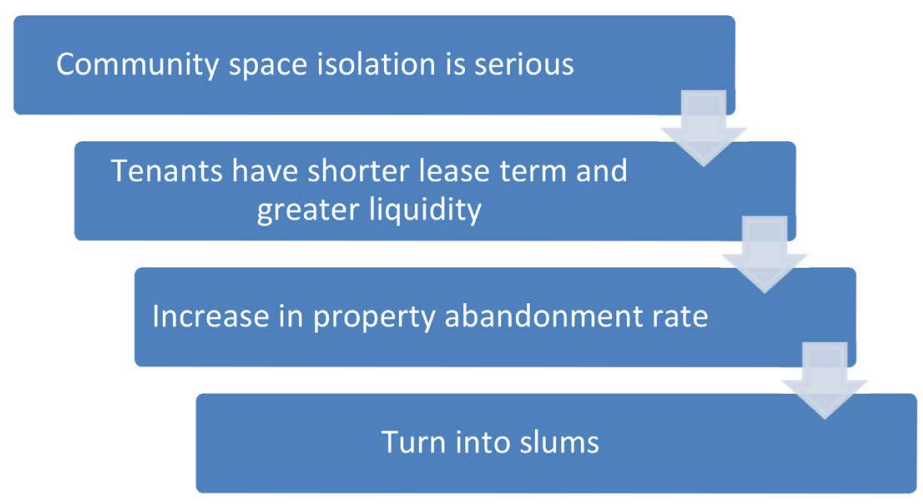

Figure 2. Transformation process of public rental housing community into slum.

housing community into slum.

3) Existing problems of "quasi-slums" in China

a) Residents live in distress, find it difficult to make a living, and lack of social security. Most of the residents are poor and do not enjoy the benefits of economic and social development that citizens should enjoy. They often play the role of tricycle drivers, small traders and peddlers on the edge of the city. They have simple food and clothing, and tend to focus on material needs and low level of spiritual consumption [11].

b) The living environment is dirty and messy, and there are many security risks. Because the supervision is not in place, the personnel is mixed, those places become the dens for criminals to hide, some people in the slums engaged in counterfeiting and selling counterfeit and other criminal activities. The alley is narrow, the street is narrow, the portal is short, the temperature is high, the population density is large, and the wire is aging and easy to catch fire.

c) Serious deficiencies in municipal and health facilities, especially latrines, water supply and electricity. Modern appliances such as air conditioners are rarely seen. Summer fan, winter stove. There was no sewage, and the used water had to be dumped on the sides of the house. Municipal sewage treatment facilities and their underground pipe network do not match the sewage discharge system, which is difficult to connect. Domestic sewage is mainly discharged by open ditches, open channels and seepage wells, which seriously pollutes the living environment.

d) The building is random and disorderly. Buildings of the Ming and Qing Dynasties, roads of the Republic of China, many houses are built by themselves, and of poor quality. Large-scale and high-density illegal buildings have been demolished and built repeatedly. Besides, as the floating population gathers in "urban villages", it is far from being able to meet the living needs of the floating population only by relying on self-owned houses, so the rental area is enlarged on the original homestead or by renovating. Due to the consideration of low cost and rapid increase of profits, many rental houses cannot meet the requirements of safety, and the simple and shabby houses built by private construction seriously affect the living safety of renters. 
e) A large number of migrants. There is a positive correlation between the change of "urban villages" and the number of floating populations. The number of floating population and registered population is inversely related. Social security is chaotic, the population is mixed, mostly the elderly, the disabled, the laid-off and unemployed, and the number of social low-income households and two-way workers is huge.

f) The reconstruction investment is huge and the financial burden is embarrassing. The investment in the overall transformation of urban villages is huge and it is difficult to promote it in a large area. The financial pressure of demolition and construction alone is enough, let alone the huge amount of compensation for demolition and social security connection between urban and rural areas.

\section{Conclusions}

After a comprehensive analysis, there are many differences in the rural land resource property rights and human resource property rights systems between China and India. This situation directly leads to the difference in poverty alleviation. Chinese farmers enjoy the protection of resource property rights. Not only that, Chinese farmers also enjoy many resource rights. Therefore, the poverty reduction efficiency is better than that of India. So, China does not have "Slums". However, according to the property rights analysis of land resources, China relies on the government to actively implement the land reform system, comprehensively solve the problem of landlords, and fairly divide the land to all farmers. Farmers have certain rights and can enjoy independent management. India draws lessons from the British democratic election system. The traditional landlord class has a certain ability to intervene. Land cannot be equally distributed to farmers like China. The rights and interests of Indian farmers have been restricted in many aspects [12]. According to the analysis of human resources property rights, China does not discriminate against women like India and respects women more. Moreover, India has implemented relatively strict labor laws and regulations, which has limited the employment of farmers, while China has protected the human resources property rights of Chinese farmers, and it's also an important reason for China's success in poverty alleviation.

But, at the same time, China's “quasi slums” problem should also be concerned. If some problems of shanty towns and public rental housing are not solved, it will have a serious negative impact.

\section{Conflicts of Interest}

The author declares no conflicts of interest.

\section{References}

[1] Qi, C.Q. and He, F. (2005) Urbanization and Slum Problem. Open Guide, 12, 1, 24-27. 
[2] Liu, Y.Q. and Yu, S.X. (2020) Comment on the Legislative Model of Poverty Alleviation abroad and China's Path Choice. Social Sciences abroad, 6, 93-104.

[3] Li, P.L. (2005) The Logic of Rebuilding "Urban Villages": Policy and Property Rights Replacement Fund. Modern Urban Research, 5, 14-17.

[4] Lei, A.Q. and Yang, G.T. (2018) International Comparison of China's Targeted Poverty Alleviation Policies: A Case Study of India and Brazil. Price Theory \& Practice, 12, 103-106.

[5] PEI, R.R. (2004) Reflections on the Difficulties Faced by Urban Vulnerable Groups. Shanxi Architecture, 3, 86-87.

[6] Lan, Z.Y. and Zhang, T. (2018) Comparison of Poverty Alleviation Experience in India, Brazil and China. Population and Society, 34, 3-15.

[7] Zhang, W.F. (2019) Poverty in India: Sources and Flows. Yunnan University.

[8] Zhang, Y.K. (2020) The Exploration and Inspiration of Solving the Housing Problem in India. Housing Industry, 10, 44-48.

[9] Li, N.S. (2000) Thoughts on Urban Shantytown Prevention and Control. Urban Development Research, 1, 32-34.

[10] Liu, Z.L. and Li, J. (2010) Public Rental Housing Policy: Basic Model, Policy Transformation and Its Reference. Modern Urban Research, 10, 21-26.

[11] Yu, H.N. (2008) Reflections on the Problem of "Slums" in China. People's Business (Economic Theory Research), 1, 135-137.

[12] Gupta, I. and Guinn, P. (2015) Health Status and Access to Health Services in Indian Slums. Health, 7, 245-255. https://doi.org/10.4236/health.2015.72029 